\title{
Timothy cultivars in a New Zealand high country environment
}

\author{
L.A. MAUNSELL and D. SCOTT \\ AgResearch, Po Box 60, Lincoln
}

\begin{abstract}
Herbage yields of 12 timothy cultivars and 4 control grasses were compared over 4 years under 50250 and 500 (with irrigation) $\mathrm{kg} \mathrm{N} / \mathrm{ha} /$ year in the South Island high country near Lake Tekapo. Timolhy produced high yields (10.9-12.2 t/ha/year) of quality herbagc under high nitrogen and irrigation. Mean yields at 50 and $250 \mathrm{~kg} \mathrm{~N} / \mathrm{ha} /$ year were 4.8 and $7.1 \mathrm{t} / \mathrm{ha} /$ year respectively under dryland conditions. Differences between the timothy cultivars were small but Grasslands Kahu was the top- or near the top-performing of the 12 cultivars tested at all times.
\end{abstract}

Keywords: cultivars, high country, Phleum pratense

\section{Introduction}

In New Zealand, timothy (Phleum pratense L.) is generally considered to be a hay species for fertile, moist soils, with red clover as its companion legume. However, it is also a valuable grazing species of good _palatability that reputedly also gives high animal growth rates. It is probably more widespread than is appreciated in mixed pastures, since it is generally kept short under a grazing situation and is therefore difficult to recognise. When conserved for hay its distinctive seed-head emerges, and its presence and productivity can readily be seen.

Earlier trials in the South Island high country showed that Grasslands Kahu timothy was a highyielding grass under irrigation at three soil fertility levels (Scott \& Maunsell 1981). The timothy had been -managed under a 6-week cutting_cycle compared with 13 other grass species having a 4 -week cutting cycle. The same trial showed that the advantage to timothy may not have been as great under a common cutting cycle. Under dryland conditions, with the same three fertility conditions, timothy was in the middle of the range of yields compared with the other grass species.

In Britain and North America, timothy is predominantly used as a hay species. Typical plant characteristics include: slow establishment; low root mass and depth: low competitiveness; early spring growth; reduced growth rate in mid summer: slow regrowth following cutting: good palatability of young foliage; higher yielding under long cutting cycles; and persistence under winter and early spring grazing (Spedding \& Diekmahns 1972; Powell \& Hanson 1978). While timothy has the reputation of being a good pasture species, there is little information on the nutritional value to grazing animals. A 3-year Welsh study showed that animal performance on timothy exceeded that of perennial ryegrass. tall fescue and cocksfoot (Davies \& Morgan 1978).

The objective of the trial described in this paper was to compare a range of timothy cultivars with four commonly grown grass species in the South Island high country, under a common superphosphate level but contrasting nitrogen $(\mathrm{N})$ fertiliser and moisture levels.

Materials and methods

The trial was established at the AgResearch Mt. John trial site, Lake Tekapo in spring 1989 and measured until 1994. The mean annual rainfall is about $520 \mathrm{~mm}$ but variable. The soil at the site is an upland yellow. brown earth of loess over-laying loess or alluvium (Webbet al. 1982; Webb 1992). The original vegetation consisted-of-fescue-tussock-and-hieracium. In the ? years preceding the trial, the area had been 4 years under a pure Grassslands Pawera red clover stand, followed by 3 years under winter greenfeed crops. The area was cultivated in late winter 1989 and the grass drilled as pure stands in $\mathbf{1 . 5} \mathrm{m}$ drill strips in mid October. Individual plots were $1.5 \mathrm{~m} \times 16 \mathrm{~m}$, with a total trial area of 0.25 ha. Measurements were started in October 1990.

The trial consisted of 12 timothy cultivars and 4 control grasses (Table 1) with $3 \mathrm{~N}$ fertiliser levels and 2 spatial replications. The four-control-grasses-were cocksfoot (Dactylis gfomerata L.). Yorkshire fog (Holcus lanatus L.), tall fescue (Festuca arundinacea Schreb.) and perennial ryegrass (Lolium perenne L.). The three fertitiser treatments were 50250 and $500 \mathrm{~kg}$ $\mathrm{N} / \mathrm{ha}$ /year applied as urea in three split dressings over spring and summer. The highest fertiliser treatment also received fortnightly irrigation by moveable minisprinklers. A basal spring sulphur superphosphate $(0: 8: 0: 20 \mathrm{~N}: \mathrm{P}: \mathrm{K}: \mathrm{S})$ dressing of $200 \mathrm{~kg} / \mathrm{ha} /$ year was applied to all plots. 
Measurement of herbage yields and growth rates were by fortnightly capacitance probe measurements (20/plot) taken from all plots, and calibrated against fortnightly quadrat cuts from the high nitrogen irrigated plots before defoliation. At 6-week intervals, all plots were grazed by sheep, then trimmed back to a common residual 2-4 cm level with a mower. Visual score assessments were made of acceptability to sheep and regrowth characteristics as seemed appropriate.

\section{Results}

\section{Seasonal and annual growth}

At this high country trial site. plant growth started in early September and has usually ceased by mid May (Figure 1). By the end of October, growth rates were high. The three $\mathrm{N}$ fertiliser treatments had rapid rises in growth rates in early spring. that of the high (N) plus irrigation treatment continuing to increase until late December. Growth rates decreased in summer and autumn under both the irrigation and dryland treatments, There was no growth over the winter period.

The timothy cultivars and other grass species are listed in approximate merit order on the basis of all plant growth characteristics assessed (Tables 1 and 2). Differences in annual yields were greater between the four control grasses than between cultivars within timothy. Timothy had similar annual yields to perennial ryegrass. tall fescue and Yorkshire fog under the three fertility treatments. There were no significant differences between timothy cultivars for annual yield at the high and moderate $\mathrm{N}$ levels. Goliath had significantly less yield at the low $\mathrm{N}$ level. Cocksfoot was the highest yielding grass under low $\mathrm{N}$; however. it was the lowest yielding under high $\mathrm{N}$ and irrigation.

While slower to establish than the control grasses, timothy cultivars remained persistent and productive. This compared with the loss of plants and stand density of cocksfoot and Yorkshire fog over time. Grasslands Kahu. Aberystwyth S48, and Intenso were the top timothy cultivars for growth rate under high
Table 1 Mean annual yield (tonne DM/ha/year) of 12 timothy cultivars and 4 control grasses, under a 6-weeck cutting cycle over 4 years.

\begin{tabular}{|c|c|c|c|c|c|}
\hline Species & Code & Cultivar & $\begin{array}{l}\text { High } N \\
+ \text { irrig. }\end{array}$ & $\operatorname{Mod} N$ & Low N \\
\hline Timothy & $\begin{array}{l}1 \\
2 \\
3 \\
4 \\
5 \\
6 \\
7 \\
a \\
9 \\
0 \\
a \\
b\end{array}$ & $\begin{array}{l}\text { Grasslands Kahu } \\
\text { Aberystwyth } \mathbf{S . 4 8} \\
\text { Erecta RvP } \\
\text { Goliath } \\
\text { Intenso } \\
\text { Sk45 } \\
\text { Motim } \\
\text { Essex } \\
\text { Oakmere } \\
\text { Pecora } \\
\text { Milton } \\
\text { Tarmo } \\
\quad \text { Mean }\end{array}$ & $\begin{array}{l}11.83 \\
12.21 \\
12.11 \\
12.01 \\
11.55 \\
\text { ii. } 38 \\
11.63 \\
11.62 \\
11.26 \\
11.21 \\
11.24 \\
10.93 \\
11.58\end{array}$ & $\begin{array}{l}7.30 \\
7.59 \\
7.25 \\
7.17 \\
7.09 \\
6.46 \\
7.34 \\
1.27 \\
7.28 \\
7.29 \\
6.80 \\
6.51 \\
7.11\end{array}$ & $\begin{array}{l}4.86 \\
4.33 \\
\\
4.55 \\
5.16 \\
4.84 \\
4.97 \\
\\
4.94 \\
4.60 \\
4.75 \\
4.50 \\
4.75\end{array}$ \\
\hline $\begin{array}{l}\text { Cocksfoot } \\
\text { Yorkshire fog } \\
\text { Tall fescue } \\
\text { Perennial } \\
\quad \text { ryegrass }\end{array}$ & $\begin{array}{l}K \\
M \\
R\end{array}$ & $\begin{array}{l}\text { Grasslands Kara } \\
\text { Massey Basyn } \\
\text { Grasslands Roa } \\
\text { Grasslands Nui }\end{array}$ & $\begin{array}{r}a .81 \\
11.79 \\
11.47 \\
11.32\end{array}$ & $\begin{array}{l}6.82 \\
7.08 \\
7.03\end{array}$ & $\begin{array}{l}6.33 \\
5.87 \\
5.37\end{array}$ \\
\hline $\operatorname{LSD}(5 \%)$ & & Overall Mean & $\begin{array}{c}0.83 \\
11.37\end{array}$ & $\begin{array}{l}1.33 \\
7.11\end{array}$ & $\begin{array}{l}0.59 \\
4.98\end{array}$ \\
\hline
\end{tabular}

Table 2 Comparative growth characteristics of 12 timothy cultivars and 4 control grasses under a 6-week cutting cycle.

Growth: $\quad H=$ high average growth rate across all conditions, $L=$ low. Nitrogen: $H=$ better at high nitrogen, $L=$ better at low nitrogen. Year: $\quad I=$ increasing over 4 years, $D=$ decreasing over years. Season: $\quad E=$ better early season performance, $L=$ better late season. Stock Acceptability: $H=$ high, $L=$ low.

blank $=$ intermediate or no consistent trend.

\begin{tabular}{|c|c|c|c|c|c|c|}
\hline Species & Cultivar & Growth & Nitrogen & Years & Season & Accent. \\
\hline Timothy & $\begin{array}{l}\text { Grasslands Kahu } \\
\text { Aberystwyth S.48 } \\
\text { Erecta RvP } \\
\text { Goliath } \\
\text { Intenso } \\
\text { Sk45 } \\
\text { Motim } \\
\text { Essex } \\
\text { Oakmere } \\
\text { Pecora } \\
\text { Milton } \\
\text { Tarmo }\end{array}$ & $\begin{array}{l}\mathrm{H} \\
\mathrm{L} \\
\mathrm{L} \\
\mathrm{L} \\
\mathrm{L}\end{array}$ & $\begin{array}{l}\mathrm{H} \\
\mathrm{H} \\
\mathrm{H} \\
\mathrm{L}\end{array}$ & $\begin{array}{l}1 \\
1 \\
1 \\
D\end{array}$ & $\begin{array}{l}\mathbf{E} \\
E\end{array}$ & $\begin{array}{c}\mathrm{H} \\
\\
\mathrm{H}\end{array}$ \\
\hline $\begin{array}{l}\text { Cocksfoot } \\
\text { Yorkshire fog } \\
\text { Tall fescue } \\
\text { Perennial ryegrass }\end{array}$ & $\begin{array}{l}\text { Grasslands Kara } \\
\text { Massey Basyn } \\
\text { Grasslands Roa } \\
\text { Grasslands Nui }\end{array}$ & $\begin{array}{l}H \\
H \\
H\end{array}$ & $\begin{array}{l}L \\
L\end{array}$ & $\begin{array}{l}D \\
D \\
1\end{array}$ & $\begin{array}{l}L \\
L \\
L\end{array}$ & $\begin{array}{c}H / L \\
L \\
H\end{array}$ \\
\hline
\end{tabular}

nitrogen. Grasslands Kahu, S48 and Erecta RvP also increased in performance over the four years of the trial. Four of the timothy cultivars were notable for 
Figure I Mean seasonal growth rates (kg/ha/day) over 4 years of 12 timothy cultivars plus 4 control grasses under contrasting $\mathrm{N}$ fertiliser levels. Low $=50$, Mod $=250$ and Hight $+\mathrm{I}=550 \mathrm{~kg} \mathrm{~N} /$ ha/year fertiliser and irrigation. Growth rates attributed to the mid-date of each cutting cycle.



Figure 2 Graphical genotype-environment analysis of growth rates of 12 timothy cultivars and 4 control grasses. The horizontal scale represents the mean yield as a percentage of the grand mean. The vertical scale the adaptability coefficient where high values indicate a greater increase relative to general increase in better environments. Cultivar coding in Table 1. Ellipse = mean standard errors for the two indices.

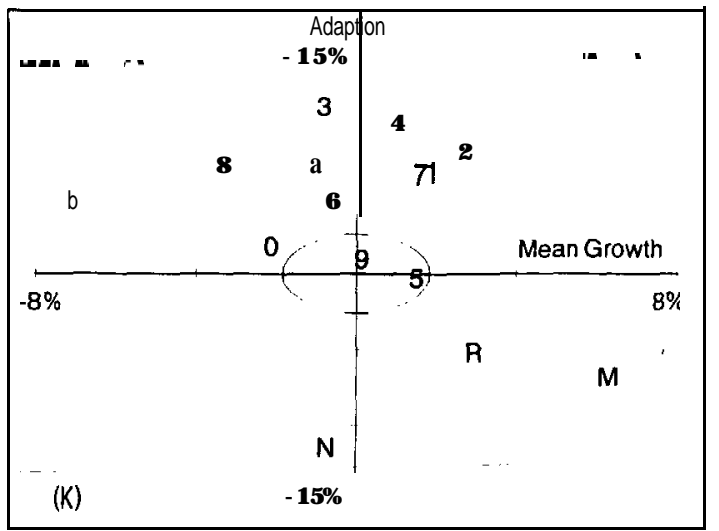

their early-season growth (Table 2). In the initial establishment of the trial, Tarmo was the most rapidly establishing of the timothy cultivars, but had the lowest mean annual yields.

Visual scores made on seven occasions following common grazing of species, showed differences in acceptability and utilisation (Table 2). There was no consistent trend within the timothy cultivars. which were all highly acceptable. The acceptability and utilisation of Yorkshire fog was consistently low, while that of perennial ryegrass was high. Utilisation of cocksfoot was variable, being high in the first two years, but low in the third year as it declined in plant numbers.

\section{Genotype-environment analysis}

The growth of the grass species and cultivars in "environmental" combinations of fertiliser treatment, seasons and years, can be combined in a genotype $x$ environment analysis (Scott 1985). The analysis compares the relative performance of cultivars as the mean growth conditions increase across the combination of "environmental" conditions (Figure 2).

The differences in growth rates among timothy cultivars were small. The cultivars in general showed a greater increase in yield in better growing conditions relative to the other grasses (positive adaptability values). Within the timothy cultivars, there was a general trend for those with higher mean growth to do proportionally better in better growing conditions, though Intenso $(=5)$, Oakmere $(=9)$ and Pecora $(=0)$ showed somewhat less variation with growth conditions

By contrast, the control grasses had high mean growth rates (high values) and maintained these across a range of growing conditions (negative adaptability values). Cocksfoot had low mean performance (-6.0\%) but maintained it across the different growth conditions (adaptability coefficient $-34.4 \%$ ). The discrimination between species and cultivars, as indicated by the mean standard error of the two coefficients, was greater for -the-adaptability-coefficient than-formean'growth.

\section{Discussion and conclusions}

The contribution of timothy to pastures, including high country pastures, is generally underestimated. The present results show that it is a very high producer in the high country under high fertility and irrigation. It remains a productive species even at low inputs. In that respect it is similar to Yorkshire fog and red clover.

This study, done on upland yellow-brown earths, reaffirmsthc findings reported in the earlier studies on upland yellow-grey earths (Scott \& Maunsell 1981) of the potential for high growth rates from timothy. Timothy had also shown very high early spring growth rates in the previous study. The nutrient content of timothy also indicated that it may be more nutrient efficient than other grass species. However, the reported low level of sodium in timothy (Spedding \& Diekmahns 1972) might be of concern for its use in inland New Zealand conditions. 
The poor performance of cocksfoot under high $\mathrm{N}$ plus irrigation conditions contrasts with its general superiority under other conditions in this environment. We attribute this poor performance to its high crown being more adversely affected by the cutting height used and the consequent reduction in plant density.

An element of caution is needed in using the seasonal growth patterns and annual yields presented. There was considerable variation among growth periods and years relating to variation in climatic conditions. and any extrapolation of the values must make full use of the estimated coefficients of variation given (22 to $37 \%)$.

The high timothy yields were achieved under seemingly high fertiliser $\mathrm{N}$ levels by New Zealand standards. However, these levels are of the order of legume $\mathrm{N}$ fixation on these high country mineral soils (Scott \& Maunsell 1981). Even as applied N fertiliser. the amounts may be justifiable to ensure winter feed supplies. or for special-purpose pastures.

In summary. timothy is an equal. or superior, performer to other grasses under high fertility and adequate moisture, and is a contender in lower fertility conditions as well. Grasslands Kahu remains among the top performing cultivars under New Zealand high country conditions.

\section{ACKNOWLEDGEMENT}

Ravensdown Fcrtiliser Ltd. for supplying the fertiliser.

\section{REFERENCES}

Caradus, J.R. 1988. Pcrformanceof six timothy (Phleum pratense L.) lines in pure swards under grazing. New Zealand journal of experimental agriculture 16: 109-112.

Davies, D.A.; Morgan, T.E.H. 1978. Grazing comparison of four grass species. Welsh Plant Breeding Station Annual Report for 1978: 68-69.

Powell, J.R.; Hanson, A.A. 1978. Timothy in Forages. The science of grassland agriculture. Heath, M.E.; Metcalfe, D.S.; Barnes, R.F. (eds), 3rdedition, lowa State University Press, Ames.

Spedding, C.R. W.: Diekmahns, E.C. 1972. Timothy. In: Grasses and legumes in British agriculture. Commonwealth Bureau of Pastures and Field Crops. Bulletin 49: 199-214.

Scott, D. 1985. Plant introduction trials: genotypeenvironment analysis of plant introductions for the high country. New Zealandjournal of experimental agriculture 13: 117-I 27.

Scott, D.: Maunsell, L.A. 1981. Past\&irrigation in the Mackenzie Basin. 1. Species comparison. New Zealandjournal of experimental agriculture 9: 279290.

Webb, T.H. 1992. Soils of the Upper Waitaki Basin, South Island, New Zealand.

DSIR Land Resources scientific report No. 3.

Webb, T.H.; Bennett, C.M.: Robertson, J.S. 1982. Soil survey of Grasslands Division Mount John trial site. Soil Bureau district office report CH 12, Deparment of Scientific \& Industrial Research, New Zealand. 